\title{
Journal of Arts and Social Sciences
}

\author{
https://ojs.jass.pk
}

\section{Induction Program of Teacher Training of Khyber Pakhtunkhwa in the Light of Standards for Elementary Teachers in Pakistan \\ Dr. Muhammad Indris*, Dr. Itbar Khan**, Adil Khan***}

\begin{abstract}
* Assistant Professor, Department of Education, Abdul Wali Khan University Mardan, midrees@awkum.edu.pk.
**Assistant Professor, Department of Education, University of Malakand, itbarkhan@uom.edu.pk.

*** Adil Khan, Department of Education, National University of Modern Languages Islamabad.
\end{abstract}

\section{A R T I C L E I N F O}

Article history:

Submitted 18.01.2021

Accepted 28.06.2021

Published

Volume No.8

Issue No. I

ISSN (Online) 2414-8512

ISSN (Print) 2311-293X

DOI:

Keywords: Teacher

Education, Pre-service, Inservice, induction, Khyber Pakhtunkhwa
A B S T RA C T

This study looked atthe induction training program introduced by the government of Khyber Pakhtunkhwa in the light of National Professional Standards for Elementary Teachers (NPSET) in Pakistan. For this purpose, five necessary standards for teaching were compared with the induction training. Qualitative research design was used, 20 teacher trainees were purposively selected for detailed interview based on five National professional Standards for Elementary Teachers in Pakistan. The data were analyzed through thematic analysis technique, the interviews were transcribed, categorize and then thermalized. From data analysis it was found that induction program was not based on national professional standards as the focus of induction was not on professional development of teachers rather its focus was on content teaching. It was recommended that induction should bring some changes within its practice as this program needs to focus more on professionalism rather content teaching and hence must focus on professionalism rather content teaching.

\section{Introduction}

Teacher education aims to make teachers proficient and efficient to face the possible challenges in their respective fields. Quality of learning is totally dependent on quality of teaching, if you have quality teachers then the quality students are the byproduct (Sultana, 2009). Initially, the program of teacher preparation was called teacher training (Lal, 2016). It, prepared teachers as mechanics or technicians. It had narrower goals with its focus being only on skill training. The perspective of teacher education was therefore very narrow, and its scope was limited. As W.H. Kilpatric put it, -we can train animal but cannot educate them we can only educate human beings (Source).

Teacher education is the combination of three core things; first, teaching skills, includes providing training to teachers necessary for instruction, planning, usable assessment technique, and all those skills necessary for instruction. Second, pedagogical theory, includes providing philosophical, sociological and psychological considerations to teachers to enable them to practice teaching skills in classroom. Third, professional skills, includes all those necessary skills for the profession, like: counselling skills, interpersonal skills, computer skills (Lal, 2009).Teacher preparation programs should aim at developing teacher the proficiency level of general education and personal culture, the expertise to utilize available resources, the ability to teach and educate others, the awareness of principles which inspire good human relations and a sense of responsibility to contribute both by teaching and by example for overall development of a country. Ibrahim (19990 opined that teacher education needs to be updated with the changes in society, it should be a dynamic, not a static process. 


\section{Modes of Teacher Education}

There are mainly three types of teacher educations., In-service teacher education is an attempt of training in-service training through certain activities and courses to upgrade their professional knowledge, skills, and competence in the teaching profession (Osamwonyi, 2016). Effective teachers constantly learn and update their teaching skills and share successes and challenges with fellow educators. Therefore, it includes all forms of education and training given to a teacher who is already on the job of teaching and learning.

The purpose of in-service teacher education programs is to update the knowledge, skills of the teachers about teaching Siddiqui (2008). Teachers need upgrading their knowledge, skills because the skills appropriate for generation ago might no longer prepare students for the world beyond school. Students are being tasked to be more creative and thoughtful in their daily activities (Fisher (2003).Those programs by which a person is trained before he enters to the professional field are called pre-service teacher education programs which are mostly provided by teacher education institutions. In April 2009, the Preservice Teacher Education Program (Pre-STEP) National Steering Committee directed the establishment of a national task force of well-known educators from all around the country to conduct an investigative study on the current patterns, policies, and programs of pre-service preparation of teachers and hence to recommend usable courses and programs based on National professional standards for teachers. Consequently, the programs of pre-service teacher education in Pakistan were revolutionized, 4-year degree program were introduecd (MoE/GoP, 2009).

Induction usually means the period or programs during which new teachers are supported in their new profession. The teacher induction period refers to the transitional period between pre-service preparation and continuing professional development, including the first few years of teaching (Huling-Austin, Odell, Ishler, Kay, \& Edelfelt, 1989). It is an intense phase in which teachers learn many things and must deal with the typical difficulties of beginning teachers (Huberman, 1989; Veenman, 1984).Induction is a process of introducing new teachers into their new roles, both as teachers and as members of the school organization. As new members of the school organization, they often must compete for a place amongst the more experienced teachers, adjust to the main school culture, and earn the gratitude of colleagues (Kelchtermans \& Ballet, 2002; Zeichner \& Gore, 1990). Beginning teachers' induction period is very vital in view of their further careers. Teachers form their professional individuality, construct a professional practice and often decide to stay in the profession or to leave it (Feiman-Nemser, 2001). A still increasing number of schools supports beginning teachers with an induction program: a formal program that is meant to support new teachers in their first years of teaching after their pre-service education (Beijaard, Buitink, \& Kessels, 2010). Due to cultural differences and local policies, to some extent goals and content of induction programs in various countries differ. However, it is gradually known that induction programs are crucial, for even a very comprehensive teacher education program cannot prepare teachers for their job completely (Britton, Paine, Pimm, \& Raizen, 2003).

\section{Teacher Induction Program in Khyber Pakhtunkhwa}

In 2013, Pakistan Tehreek Insaf (PTI) got lead in KP and established their government. The manifesto of this political party was to bring change in KP various departments, of which education was the priority. Thus, taking advantage from $18^{\text {th }}$ amendment, the KP government also initiated some reforms including independent monitoring unit, developing school infrastructure, and increase in enrollment rate and many others. These reforms according to (Alif Ailan, 2107; ASER, 2107) reports brought some positive changes. However, one of the recent education reforms -New teacher Induction Policy- had been criticized by various stake holders in education department (Ahmad, Ali. 2018). This new policy was approved from provincial cabinet and on priority basis it was implemented. In this policy the previous criteria for teacher recruitment was revised and new policy for all cadres was introduced.

\section{Rationale behind Policy}

The KP government conducted a study to explore the quality of primary teachers in (Ahmad, Ali, 2018), and found that the content knowledge of the teachers was weak. But, this survey has been criticized by many researchers as Reba (2017) a survey test for measuring the competency level of primary teachers, was 
conducted. Unfortunately, only $7 \%$ of the total participated teachers were able to qualify the survey test. The findings of the study were generalized on all other cadres and at the end this study recommended that necessity of professional qualification in teacher induction policy should be demolished. Although, according to Ahmad, Ali, (2018) this study was criticized by (Ali, 2017) in Peshawar during a presentation in a seminar on "Teacher professional qualification" he stated that "I have many points to criticize on this study. First, the purpose of the survey test was not disclosed with the participant which is against ethical consideration of the research. Second, the selected sample was not appropriate representative of the population. Hence, the study conducted by KP government and the recommendation of that study was the reason of revising the induction policy of teachers and demolishing professional qualification as an important condition for teaching. The current study is designed to look at the curriculum of the induction program from the perspective of the standards of teacher education from the perspectives of standards designed for elementary teachers in Pakistan. These standards are the results of great deliberation and hard work, and this was the first attempt to streamline the teacher education in the country. The study have implications for teacher education in Pakistan.

\section{Statement of the Problem}

Teacher education is crucial for effective teaching in classroom, because it enable teacher to perform duties more effectively. The KP government changed the year olds system of recruitment, and introduced a new type of induction program- recruiting untrained teachers, and then giving them training in an untraditional way. This mode of induction has been criticized by educations (Sohail, Barkat, 2017; Ali, 2018; Reba, 2017) and many others. The current study is focused on the curriculum, and process of the induction program in KP from the perspectives of newly recruited teachers and in the light of the National Professional Standards for teachers in Pakistan.

\section{Research Questions}

The following research questions were formulated:

1. How is induction program practiced in Khyber Pakhtunkhwa?

2. How far are the professional standards in Pakistan followed in the induction program initiated by KP government?

\section{Nature of the Research}

The focus of the research was to analyze induction program from trainee perspective and to compare the induction program with 05 National Professional Standards necessary for teaching. The researcher adopted qualitative research design for conducting research study. Purposive sampling technique was used for data collection, 20 newly inducted teachers wereinterviewed for data collection. Interview questions were developed after going through National Professional Standards and discussion with the trainees. Hence, 5 interviewed questions were framed. The first question was related to the content science, Urdu, English and Math, in the induction program. Second, a question about teaching method and satisfaction of the trainees was included, and the third was was about the teaching of assessment in the program. Similarly, the fourth was asked about creating collaboration between school and community, and the last one was about the integration of ICT in the education. All these are based on the standards teachers.

\section{Data Collectionand Analysis}

To collect data from the selected respondents, the researchers personally visited different schools and requested headmaster of the school to allow him to collect data from the respondents. Data were collected through semi-structure interview which helped researcher in getting information, perception, beliefs and values of the participant (Tuckman, 1972). Semi structure interview is well-suited for the investigation of the belief and point of view regarding issue and helped the researcher to get more information, elaboration and clarification of answers (Barribal \& Whiles, 1994; Cohen et al., 2007). The researcher recorded the interview with the consent of the interviewee. Thematic analysis technique was used for analyzing the data in the first step the researcher identified codes within the transcribed interviews then the process of categorization was done in result of which certain categories were identified and then themes were identified from the categories. The themes were analyzed.During thematic analysis 09 themes emerged regarding Induction programs from the perspective of teacher trainees. Following is the list of themes emerged from data analysis. 


\section{Lack of Urdu}

Urdu is a compulsory subject from grade 1 to 12 grade but it was found that there was nothing in the induction program about Urdu. This was one of the main deficiencies in the induction program and this a fact that our teachers, like, other subjects need improvement in the content of Urdu as well. All the respondents mentioned that there was no content on Urdu in induction program which is not a good sign for new teachers. For example, teacher 16 said: “...the content of induction program only consisted of English, Math and science hence, Urdu wasn't part of the program..." Likewise, teacher 7by responding to a question "whether they had covered the content of English, Math, Science and Urdu"said: "...the subjects you asked about was part of the induction program and they worked on it but not on Urdu...". Similarly, teacher10, by sharing his views about content of Urdu said: “...yes, they worked on the content, but Urdu wasn't part of the program they mainly stressed on science and Math...".

\section{Level of the Content}

Some of the respondent talked about level of the content. They shared the views that the content of induction program was not of the primary level for primary teacher the content was difficult. If, focus of the program was on content then there should have content of primary level with some techniques of teaching. For example, teacher 12 said: "...the content of the induction program was not of the primary level and it was that of secondary or middle level. We, primary teachers should have been trained in the content of primary level, similarly, for middle school teacher the content was that of Inter level in the program..." In the same vein teacher 5 opined, "...personally, I am not satisfied from the content. They should have trained us in content of primary level because I, in future, will be the teacher of primary level..." It is inferred that the content pf the induction program was not according to the level of the teachers, and thus they might have not have learned much.

\section{Lack of Competent Instructors}

Teacher educators are considered to be role model, in attitude, skills and competency. The trainees not only learn from the content but from the behavior and conduct of the trainers as well. The trainers themselves must be well versed in the field of educating future teachers. Some of the respondent said that, their trainers were not competent for training the trainee teachers. There should be specialist teachers for teaching content to the trainees. For example, teacher 14 responded to the question whether their trainers were competent in the area which they taught. "No, our science teacher was promoted SST and hence was not competent in teaching science and math...".

Similarly, teacher 18, by responding to same question said: “...our master trainer for science was that of MA Islamiatand hence wasn't aware from the very basic things of science". Teacher3 sharing his views regarding selection of trainer's said:

“...there must be scrutiny for selecting teacher trainers and only competent one should be selected. The trainers selected, must know the process of training the trainees, objectives of the program but, in induction it wasn't the case because promotion-based SST's were selected as master trainers for science and math..." Teacher 20 opined, "... they only taught us the content present there in the tablet'.

Teacher 6 by answering question regarding their trainers said: “...I can't say I am satisfied from the trainers because, for our Math and Science there was only one SST and it was difficult for him to cover the topics of both the subjects". Similarly, teacher 12,15 shared their views about trainers and said: “...English teacher was good, he was subject specialist in English, but for science and math they assigned only one senior science teacher..."

\section{Lack of Teaching Methodologies}

Teaching methodologies are essential for proper interaction of students with the content but in the instant case quiet a lot of respondents mentioned that there was nothing about teaching methodologies in the induction program, there was not any content about teaching methods, and most of the trainers did not discuss teaching methodologies of the content which they taught. For example, teacher 4 said: “...they haven't taught us content about teaching methodologies and only told us teaching based on lesson planning". 
Similarly, teacher 12 said: “...they didn't teach us teaching methodologies nor any techniques. The trainers were having their own guidebook provided by the government and they followed that book...".

Teacher 10 opined, “...there was no such content on teaching methodologies they only taught us the content present there in the tablet PC". While, some of the respondents by responding to the question "whether, there was any content or discussion regarding teaching methodologies?" said that the trainers informally discussed the teaching methods but there was no content on teaching methods. For example, teacher 7 said: “...for teaching methodologies, in the start of every session, they use to give us hints like how you will start teaching and what you should do before starting the class but no separate content on methodologies"

\section{Lack of Content Regarding Assessment}

Assessment plays an important role in the process of teaching and learning process. This should be an important element of any training program. And assessment is standard number 5 in the standards for elementary teachers in Pakistan. The current study also investigated assessment in the induction program. It came to light that there was nothing on assessment in the whole process. For example, teacher 5, in response to the question whether they learned something regarding assessment, said: “...concerning to the professional development I am not satisfied because the focus of the program was only on content hence, there was nothing for our professional development...".

Similarly, teacher 4 by responding to a question regarding assessment said: “...we haven't learned anything regarding assessment, nor they taught us content regarding assessment, and we were treated in the program like school students...”'Teacher 6 said: “...No, they haven't taught us any techniques related to assessing students. I, once told them that this is our professional development program, but we are learning what we already learned in our B.Sc.". Whileteacher 9 said about content of assessment "...they haven't taught us any content on assessment of students...".

\section{Community Involvement}

One standard for elementary teachers is related to the skills of teachers for involving community for the improvement of schools. The teachers were asked if there was any content or discussion about society involvement in the induction program. It was found that there was almost nothing in the course about the involvement of community in the matters of schools. For example, teacher 1 said: "...there was no such content which teaches us how to engage different stakeholders with the school...".

Similarly, teacher 2informed about community involvement in the induction program, “...there was no content nor any discussion on collaborating community, like we have PTC community or how to deal with education officers".

"...this was first program so the trainer himself were not aware of the process of the program and the program was even lacking necessary stationary hence, there was no such discussion regarding collaboration of different stakeholder" (Teacher 5).

\section{The Use of Information and Communication Technology (Ict) in Teaching and Learning}

The use of ICT revolutionized each field of the universe, ICT can also play an important role in the improvement of teaching and learning as well getting access to those who are inaccessible through formal education. We are living in $21^{\text {st }}$ century in which almost all the things are computerized. But, in in Pakistan the most basic sector on which all other sectors of the society are dependent is still following traditional approaches-The education sector. This study found that induction program was lacking any content regarding use of ICT for education. For example, respondent 1 said: “...there wasn't any material on integrating ICT in education. They only introduced us with tablet PC...”.

Several other respondents shared similar views regarding ICT for example, respondent no 7 said: "...the tablet PC was only availed for the trainees, they use to watch videos and prepare assignment from that tablet PC other than that there was no material about integrating ICT in education...". 
Similarly, respondent no 10 said: “...computer education wasn't part of the program. The focus was only on content teaching..." Sizeable number of respondents shared same views regarding ICT content. For example, respondent no 5 said: "...they only teach us how to use tablet PC the rest no content on ICT integration in education”. Similarly, respondent no 6 said: “...neither content nor any discussion for ICT integration except teaching us ways for solving Tablet PC related problems...".

\section{Lack of Proper Use of it Expert}

In induction program in addition to some subject experts, an IT expert was also assigned to each center. As, we know that the program was lacking any content related to ICT integration in Education as respondent no 2 said: "...there was no such content on ICT..." The role assigned to IT expert was quiet opposite to his abilities. For example, respondent no 2 said: "...the job of IT expert was to give marks on assignment, solve tablet related problems and take attendance..." Similarly, respondent no 3 said: “...the job of IT expert was to maintain labs, give marks on assignment and at the end taking attendance". Similarly, respondent no 6 by denying the presence of ICT related content and elaborating the job of IT expert said: “...no content or any discussion related to ICT integration except teaching us ways for solving tablet $P C$ related problem.

\section{Findings and Discussion}

Induction program was lacking any content of Urdu as most of the respondents mentioned that Urdu was not there in induction program. Urdu is our National language and lack of Urdu training in the program would have bad consequences for trainees.

Secondly, the content of induction program was not of the appropriate level and many respondents mentioned that we should have been trained in the content appropriate for our level. Some of the respondents mentioned that our master trainers were not that competent because they were SST but promoted SST and hence were not competent to cover most of the topics of Science and Math. Similarly, some of the respondents mentioned that their trainers were not specialist of the subjects because the trainers not related to the subject e.g. some of the participants said that their trainer were MA Islamiyat and hence were not specialist.

Teaching methodologies is an essential element in teacher education programs. The pedagogy is an essential element of the trainings as according to (Armstrong, 2007) teacher with even better understanding of content may face difficulties in teaching those content and conveying the information to their students. Teachers who are trained in teaching methodologies can use teaching techniques and may be able to use different techniques for varying abilities of students.

The participants of the research mentioned that induction program was lacking training of assessment and there was no material nor any discussion on assessment. While, many studies show that assessment is important factor for teachers as we know assessment is one of the important factors for example according to (Armstrong, 2007) teacher must know not only content but the techniques to assess as well. Similarly, another study by (Oter0, 2006) mentioned that teacher education program must train teachers in different assessment techniques so that they may use appropriate techniques in varied circumstances. In induction program mostly the focus according to many participants was on content teaching hence, the program was lacking any discussion on collaborating community with the school according to some studies for example (Armstrong, 2007) in teaching profession you cannot work in isolation. Teacher must know how to collaborate different stakeholders as, according to (Berry, 2005) to communicate with the parent is one of the qualities among some qualities of best teachers.

Additionally, in induction program the new teachers were not trained in using ICT for education we are in $21^{\text {st }}$ century and hence ICT can make our teaching learning process more easy but it was a neglect in the program as according to (Armstrong, M 2007) teacher education program must train teacher trainees so that they may effectively integrate ICT in education. According to UNESCO (1998) the growing advancement of ICT changes the way to prepare, get and transfer knowledge.

Last but not the least IT expert in the program was not properly used for the betterment of the program 
because their job in the program was to mark attendance andmost of the respondents mentioned that IT expert job was, to upload assignment marks and solve tablet PC related problems.

\section{Conclusion}

Based on the data analysis and major findings the researchers concluded that the induction is not that effective because, most of the participants were not satisfied from the induction. Firstly, in the induction program there was no content of Urdu hence, it had ignored the Importance of National language for primary students and teachers. Similarly, the content in induction program was of high level and the content was not appropriate for primary teachers and some of the respondents mentioned that they should have been trained in the primary content with certain techniques of teaching. But, the focuses only on content of three subjectsScience, Math, English and hence not stressed on the professional training of the trainees.

There was not any professional training- teaching methodologies, assessment training, ICT integration into education and lack of content and discussion on engaging the community with the school. It is concluded that the program was not in accordance with national professional for teacher because there were no certain criteria followed by the induction as mentioned in the professional standards for teachers. It is concluded that the program was not the professional training, but it was based on content teaching like students learn subjects in the school as some of the respondents mentioned that professionalism was not there in induction program.

Additionally, the researchers conclude that, although, the focus of induction was on content, but it was even far behind in teaching the content because among the trainers some of them were not competent while some of them were not relevant to the subjects. Promoted SSTs were not able to train the teacher trainees.

\section{Recommendations}

Based on the findings the researcher has put forward the following recommendations and suggestion to make the induction program more effective.

1. In induction program the government should introduce Urdu as a subject as well in addition to the three subjects. Just because we cannot ignore the effect of Urdu on students as well as on new teachers.The trainees must be trained in the content they will teach in future by the end of induction program. Like, the content for primary teachers should be that of primary level and for CT teacher the content should be that of middle level.

2. There should be fair scrutiny for master trainer selection and only subject specialist should be selected as master trainers. It will not only improve content teaching, but trainee would be trained under experienced specialist. The master trainer of the induction program should be trained in a way so that they may integrate pedagogy/teaching methods with the content and hence the trainees would be trained not only in the content but in the pedagogy at the same time.

3. The program should focus on professionalism and hence must train trainees in skills they would need in future. Like, the trainees must be train in assessment so that they may assess what they teach.

4. The induction program should introduce content related to ICT and must train teachers in using ICT for education.

5. The new trainees of induction program must be trained in the content and they may also be taught how to collaborate with the community and different stakeholders. Moreover, the objectives of induction program should be developed by looking at National professional standards.

\section{References}

Ahsan, M. (2005). Politicization of bilateral aid and educational development in Pakistan. Educational Studies, 31(3), 235-250.

Ali, S. (2009). Governing education policy in a globalizing world - The sphere of authority of the Pakistani state. Published dissertation, University of Edinburgh, Edinburgh.

Barribal, Whiles, (1994). Collecting data using semi-structure interview: a discussion paper. Journal of advanced nursing, 1994, 19, 328-345.

Beijaard, D., Buitink, J., \& Kessels, C. (2010). Teacher induction. In P. Peterson, E. Baker, \& B. McGraw (Eds.), International Encyclopedia of education, 3rd edition, volume 7 (pp. 563-568). Oxford: Elsevier. 
Berry, B. (2005). The future of teacher education [Electronic version]. Journal of Teacher Education, 56(3), 272-278.

Billing, D. (1976) The nature and scope of staff development in institutions of higher education in Elton, Lewis and Simmonds, Kerren (eds) Staff Development in Higher Education.

Chang, F. H. (2014). Globalizing teacher education in Pakistan: Its impact on program implementation. Paper published in proceedings of International Conference on Education and Social Sciences. OCERINT.org:

Chubbuck, S. M., Clift, R. T., Allard, J., \& Quinlan, J. (2001). Playing it safe as a novice teacher: Implications for programs for new teachers. Journal of Teacher Education, 52, 365-376.

COHEN, L. et al. (2007). Research Methods in Education. New York: Routledge.

Coskun, 2013.An investigation of the effectiveness of the modular general English language teaching preparatory program at a Turkish university. SA Journal of Education, Vol 33, No 3 (2013)

Darling-Hammond, L. (1999). Solving the dilemmas of teacher supply, demand, and standards: How we can ensure a competent, caring, and qualified teacher for every child. New York: National Commission on Teaching and Americaes Future.

Darling-Hammond, L., \& Bransford, J. (Eds.). (2005). preparing teachers for a changing world: What teachers should learn and be able to do. San Francisco, CA, US: Jossey-Bass

F Tuli, G File, (2009). Practicum Experience in Teacher Education. Ethiopian Journal of Education and Sciences.

Fiemen-Nemser (2001). Helping novices learn to teach. Journal of Teacher Education 52(1):17-30 • January 2001.

Fink A. (2010). Conducting Research Literature Reviews: From the Internet to Paper. 3rd ed. California: Sage Publications, 3-5.

Goldhaber, D., \& Anthony, E. (2004). Can teacher quality be effectively assessed? Working Paper, Seattle: Center on Reinventing Public Education, University of Washington

Government of Pakistan. (2009). National Education Policy 2009. Islamabad: Ministry of Education

Haigh, M., Pinder, H., McDonald, L. 2006 Practicum's contribution to students' learning to teach

Hargreaves, A. (1994). Changing teachers, changing times: Teachers' work and culture in the postmodern age. Teachers College Press. London: Redwood Books.

Helsel, et, al.2003, Safe Passages: Providing Online Support to Beginning Teachers. Journal of education. Volume: 54 issue: 4, page(s): 311-320

Hoodbhoy, P. (1998). Education and the State Fifty Years of Pakistan. USA: Oxford University Press.

Huberman, M. (1989). The Professional Life Cycle of Teachers. Teacher College Records, 91, 31-57.

Huling-Austin, Odell, Ishler, Kay, \& Edelfelt, 1989; Beginning Teacher and Mentor Relationships. Journal of education.

Ahmad, I., Zeb, A., Rehman, S., Ahmad, S., Khan, W., Ahmad, K., Ghani, A., (2012). An Evaluation of the Effectiveness of Teacher Preparation Programmes in Khyber Pakhtunkhwa Province, Pakistan. International Journal of Business and Social Research (IJBSR), Volume -2, No.-7.

Ibrahim, I. (2000), Education Guide of Pakistan (1999-2000), Ibrahim Publisher, Lahore. P-2

Ingersoll, R., \& Smith, T. M. (2004). Do Teacher Induction and Mentoring Matter? Retrieved from https://repository.upenn.edu/gse_pubs/134.

Julie, K. \& Brian, C. (2007). The Knowledge Building Community Programme: A Partnership for Progress in Teacher Education. T.Townsend and R. Bates. Handbook of Teacher Education, Netherlands. (pp397-8).

Kelchtermans, G., \& Ballet, K. (2002). The Micropolitics of Teacher Induction: A Narrative-Biographical Study on Teacher Socialization. Teaching and Teacher Education, 18, 105-120.

Kelley, M. (2004).Why Induction Matters. Journal of teacher education. Volume: 55 issue: 5, page(s): 438448.

Odell, et, al. (1992).Teacher Mentoring and Teacher Retention.Journal of education. Volume: 43 issue: 3, page(s): 200-204 Issue published: May 1, 199.

Osamwonyi, (2016). Journal of Education and Practice, v7 n26 p83-87 2016

Otero, V. K. (2006). Moving beyond the "get it or don't" conception of formative Assessment [Electronic version]. Journal of Teacher Education, 57(3), 247-255.

Poojary, S A., \& Bagadia, J. D. (2014). Reviewing literature for research: Doing it the right way. Indian Journal of Sexually Transmitted Diseases, 35(2): 85-91.

Reba, A. (2017). During PITE representative presentation, the fact has been identified that the training after selection will be for six months, whereas, in advertisement the training period is 09 months. This 
shows ignorance on the part of education depart... [Facebook Status Update]. Retrieved from https://www.facebook.com/amjad.reba on January 1, 2018.

Siddiqui, M. H. (2008). Technique of Classroom Teaching. Delhi: Balaji Offset Navm

Sohail, A, Barkat, A (2018). Khyber Pakhtunkhwa's Government and New Teacher Induction Policy: Is the Government in Harmony with National and International Trends in Teacher Education?.2nd International Conference on Business, Economics \& Education Management ICBEM 2018, At Sukkur-IBA University

Tuckman, B. W. (1972) Conducting Educational Research. New York: Holt, Rinehart \& Winston.

UNESCO. (1998). New direction of ICT-use in education. Retrieved on October 08, 2019 from http://www.unesco.org/education/lwf/dl/edict.pdf

UNESCO. (2013). Status of teachers in Pakistan. Retrieved on August 02, 2017 from http://unesdoc.unesco.org/images/0022/002272/227256e.pdf

Veenman, S. (1984). Perceived problems of beginning teachers. Review of educational research, 54(2), 143178.

Zaki, W. M. (1999). Teachers and Education Policies; In Farooq R.A. and Hafeez Ullah's Report of the National Training Workshop on Educational Planning and Management for Principals of Teacher Training Institutions, Islamabad, Pakistan. (PP 29-30)

Zeichner, K., \& Gore, J. M. (1990). Teacher socialization. Handbook of Research on Teacher Education (pp. 329-348). New York: MacMillan. 